\title{
NANO GÜMÜŞ EMPRENYE EDILMIŞ ÜÇ BOYUTLU KUMAŞLARDA ANTI-MIKROBIYYAL ETKINLIK
}

\author{
Gamze Taylan* , Ayşen Tulpar* , Alparslan Demirural* , Tarık Baykara**
}

ÖZ

Gümüşün nano boyuta indirilmesi, onun aktivasyonunu arttırarak bakteri, mantar ve virüsler üzerindeki etkisini daha da arttırmaktadır. Nano boyutlarda (0-200 nm) gümüşle temas eden bakteri, virüs veya mantar hücrelerinin metabolizması bozulmakta ve elektriksel etkileşimle enzimleri etkisiz hale getirerek hücreleri öldürmektedir. Nano gümüş emprenye edilen antimikrobiyal tekstillerde, antimikrobiyal etki iyonize nano gümüş miktarı ile doğru orantılıdır. Bu doğrultuda üç boyutlu kumaşlarda daha fazla nano gümüş iyonu emprenyesi mümkün olmakta ve antimikrobiyal etkinlik artmaktadır. Bu çalışmada, nano gümüş emprenye edilmiş üç boyutlu kumaşların antimikrobiyal etkinliği, maya (Saccharomyces cerevisiae) kullanılarak incelenmiştir. Nano gümüş emprenye edilmiş üç boyutlu kumaşlarda, ilk 3 dakika içerisinde maya hücrelerin çoğalmadığı aksine yok olmaya başladığı görülmüştür. Nano gümüş emprenye edilen üç boyutlu kumaşlarda, hücreler kumaş içerisine nüfus etmeden kumaş yüzeyinde etkisiz hale gelmektedir. 24 saat içerisinde, kumaş yüzeyinde maya hücreleri üreyip gelişemeden kumaş üzerinde kuru ve ölü bir tabaka oluşturmaktadırlar.

Anahtar Kelimeler: Nano gümüş, antimicrobial coating, üç boyutlu kumaş, emprenye

\footnotetext{
**Makale Gönderim Tarihi: 17.08.2018 ; Makale Kabul Tarihi : 24.05.2019 Makale Türü: Araştırma DOI: 10.20854 /bujse. 454358

*Doğuş Üniversitesi, Makine Mühendisliği Bölümü, Kadıköy, İstanbul

**Sorumlu yazar: Doğuş Üniversitesi, Makine Mühendisliği Bölümü, Kadıköy, İstanbul (tbaykara@dogus.edu.tr)
} 


\title{
ANTI-MICROBIAL EFFECTS ON NANO-SILVER IMPREGNATED 3-D FABRICS
}

\author{
Gamze Taylan* , Ayşen Tulpar* , Alparslan Demirural* , Tarık Baykara**
}

\begin{abstract}
Reducing the size of silver particles down to nano dimensions increases its effects on bacteries, fungus and viruses. Interacting with the nanosized $(0-200 \mathrm{~nm})$ silver, metabolism of the bacteries, viruses and fungus cells are degraded and their enzymes are getting disabled through electrical interaction and their cells eventually die. Antimicrobial textiles impregnated by nanosilver, antimicrobial effect increases linearly with the amount of ionized nanosilver. In this regard, more nanosilver impregnation is possible and the antimicrobial effect increases. In this study, the antimicrobial effect in 3 D textile fabrics impregnated with nanosilver is investigated using Saccharomyces cerevisiae yeast. On the surface of the 3D textiles, yeast cells didn't reproduce, on the contrary they eventually vanished. In nanosilver impregnated 3D textiles, yeast cells couldn't diffuse into the inside of fabrics and become ineffective on the surface. Within 24 hours, yeast cells were dried and left a lame layer on the fabric's surface.
\end{abstract}

Keywords: Nano-silver, antimicrobial coating, 3D fabrics, impregnation

\footnotetext{
**Makale Gönderim Tarihi: 17.08.2018 ; Makale Kabul Tarihi : 24.05.2019 Makale Türü: Araştırma DOI: $10.20854 /$ bujse. 454358

*Doğuş University, Department of Mechanical Engineering, Kadıkoy, Istanbul

**Corresponding author: Doğuş University, Department of Mechanical Engineering, Kadıkoy, Istanbul (tbaykara@dogus.edu.tr)
} 


\section{GíRiș}

Nano gümüş partiküller etkili ve geniş spektrumlu antimikrobiyal aktiviteleri sebebi ile istenmeyen mikroorganizmaları ortadan kaldırmak ve kontaminasyonu önlemek amacıyla kullanılmaktadır [1]. Bakteri ve virüsler bile nano gümüş parçacıklarının yanında dev yapılar olarak kalmaktadır ve nano boyuttaki $(0-200 \mathrm{~nm})$ gümüş parçacıklarına temas eder etmez hücresel yapıları bozularak ölmektedirler. Nano gümüş, antimikrobiyal tesiri ve bakterilerin antibiyotiklere karşı geliştirdiği direnci gümüşe karşı geliştirememeleri dolayısı ile uzun yıllardır bilim çevresinin dikkatini çekmeye devam etmektedir [2-4]. Nano gümüş parçacıklar, antimikrobiyal özellik kazandırılması istenen neredeyse her ürüne kaplanabilmekte ve böylece gündelik hayatta kullandığımız eşyaların son derece steril olması sağlamaktadır. Nano boyutlarından dolayı, gümüş parçacıklar herhangi bir maddenin yüzeyinde kaplı olduğunda, yüzey alanı birkaç milyon kat artarak, çok güçlü antimikrobiyal etki sağlar [5]. Nano gümüşün insan sağlığına, evcil hayvanlara bitkilere, diğer bir deyişle çok hücreli canlılara zarar vermez. Nano gümüş mikroorganizmlar ile karşılaştığında onların yapılarını bozarak ölmelerini sağlar bunu yaptıktan sonra başka herhangi bir reaksiyona katılmaz aynı zamanda reaksiyondan çıkınca da Nano gümüşün yapısı herhangi bir bozunuma uğramaz ve mikroorganizmalar ile tekrar karşılaşması halinde antimikrobiyal özelliğinden hiçbir şey kaybetmeden antimikrobiyal etkinliğine devam ederek mikroorganizmaların ölmesini sağlar.

Ayrıca, uygulama ortamına sürekli gümüş ilavesi de gerekmemektedir. $\mathrm{Bu}$ alanda üretilen ve piyasaya sunulmak üzere olan ürün sayısı oldukça fazladır; örneğin, iç yüzeyi nano gümüş ile kaplanmış buzdolapları, nano gümüş parçacıkları içeren kumaşlardan yapılan giysiler, çoraplar, halılar, antimikrobiyal perdeler, hava filtreleri, mutfak gereçleri, ayakkabı tabanlıkları vb.

Mikroorganizmaların tekstil materyali üzerinde gelişerek üreyebildikleri uzun yıllardan beri bilinmektedir. Tekstil ürünleri, yapıları ve kullanıldıkları yerler açısından mikro organizmaların yaşaması ve çoğalması için uygun sıcaklık, nem ve besin maddesi sağlayan ortamlardır. Tekstil yapılarının ara katmanlarına yerleşen mikro organizmalar, tekstil ürünün kendisine ve kullanıcıya zarar verebilmektedir. Geçmişte, tekstil ürünlerine antimikrobiyal uygulamalar, özellikle küflerin neden olduğu ekonomik kayıpları önlemek amaciyla yapılıyordu. Antimikrobiyal özellik kazandırılan tekstiller, mikro organizmaların neden olduğu olumsuzlukları azaltmaya ve ortadan kaldırmaya yardımcı olmaktadır. Bu ürün gurupları mikro organizmaların enfekte olmalarının önüne geçilmesi, enfeksiyonların kontrol altında tutulması, mikroorganizmalardan kaynaklanan koku ve lekelenme ve renk değişiminin önüne geçilmesi ve kalite kaybının engellenmesi amacı ile kullanılmaktadır. Antimikrobiyal örtüler, bakteri ve/veya mantar gelişimini engellemekte ve/ veya sınırlandırmaktadırlar. Antimikrobiyal örtülerin birçoğu hem bakteri, hem de mantarlara karşı güçlü aktivite göstermektedirler $[3,4,6,7]$.

Antimikrobiyal Örtiilerden Beklenen Özellikler:

- Mikrobiyal çoğalma üzerine etkili olmalı;

- Üreticiler ve kullanıcılar üzerine toksik etkisi olmamalı;

- Uygulandığı tekstil ürününün arzu edilen özelliklerini değiştirmemeli;

- Kokusuz ve lekesiz olmali;

- Hedef mikroorganizmalara karşı seçici olmalıdır;

- Sağlıklı dokulara zarar vermemeli;

- $\quad$ Antimikrobiyal örtï kendi yapısını bozmamalıdır; (tiftiklenme,yırtılma vb.)

Günümüzde medikal tekstillerin satış hacmi 7 milyar dolarları bulmaktadır. Antimikrobiyal apre son derece talep edilen bir işlem haline gelmiştir. Bu noktada Batı Avrupa'daki üretim toplam hacmin $\% 25$ 'ini elinde bulundurmaktadır.

$\mathrm{Bu}$ çalışmada, nano gümüş emprenye edilmiş üç boyutlu kumaşlarda antimikrobiyal etkinlik incelenmiştir. Nano gümüş emprenye edilen antimikrobiyal tekstillerde, antimikrobiyal etki, iyonize nano gümüş miktarı ile doğru orantılıdır. $\mathrm{Bu}$ doğrultuda üç boyutlu kumaşlarda daha fazla nano gümüş iyonu emprenyesi mümkün olmakta ve antimikrobiyal etkinlik artmaktadır. Maya (Saccharomyces cerevisiae) kullanılarak üç boyutlu kumaşların maya hücrelerine karşı etkinliği incelenmiştir. Nano gümüş emprenye edilmiş üç boyutlu kumaşlarda ilk 3 dakika içerisinde maya hücrelerinin çoğalmadığı aksine yok olmaya başladığ görülmektedir. Nano gümüş emprenye edilmiş üç boyutlu kumaşlarda, maya hücreleri kumaş içerisine nüfus etmeden kumaş yüzeyinde etkisiz hale gelmektedir. 24 saat içerisinde, kumaş yüzeyinde maya hücreleri üreyip gelişemeden kumaş üzerinde ölü ve kuru bir tabaka haline gelmektedir.

\section{2. Üç Boyutlu Tekstillerde Antimikrobiyal Etkinlik}

Üç boyutlu kumaşlar, iki dış yüzey ve bu iki dış yüzeyi birbirine bağlayan bir bağlantı tabakasından oluşan üç boyutlu yapıya sahip tekstil yapılarıdırlar. 
Teknik alanda üretilen kumaşlar arasında yer alan üç boyutlu kumaşlar, gelişmiş makine teknolojisi ile üretilen ve konvansiyonel tekstil yapıları tarafından karşılanamayacak özelliklere sahip özel tekstil yapılarıdır. En belirgin özellikleri, çok iyi basma dayanımı, yüksek hava geçirme özelliği, iyi esneme özelliği, kimyasallara karşı dayanıklılık, yüksek eğilme performansı ve dökümlülük olarak sıralanabilir [8]. Nano gümüş emprenye edilen antimikrobiyal örtülerin antimikrobiyal özelliklerinin, (a) iyonize nano gümüş miktarı ile doğru orantılı olduğu, (b) uygulanan kumaş iplik tekniğinin havsız ve kesiksiz elyaf ile dokunmuş olmasına bağlı olarak daha üstün olduğu değerlendirilmektedir. $\mathrm{Bu}$ sebeplerden dolayı mevcut olan 1:1 düz ayak örgü kumaş tekniğinde, kesiksiz elyaf tekniğini uygulamanın mümkün olabildiği ancak nano gümüş iyonlarının miktarının arttırılması mümkün olmamaktadır. Bundan dolayı nano gümüş iyon miktarının arttırılması maksadıyla, bu çalışmada üç boyutlu kumaşlar kullanılmıştır. Böylelikle kullanılan 3 boyutlu kumaşın hacimsel farkından dolayı çok daha fazla nano gümüş iyonu emprenye edilebilmiştir. Böylelikle, nano iyonize gümüşlerin antimikrobiyal örtüde daha yüksek miktarda olması ve kumaşın daha fazla antimikrobiyal etkinliğe sahip olması sağlanabilmektedir (Şekil 1) [9].

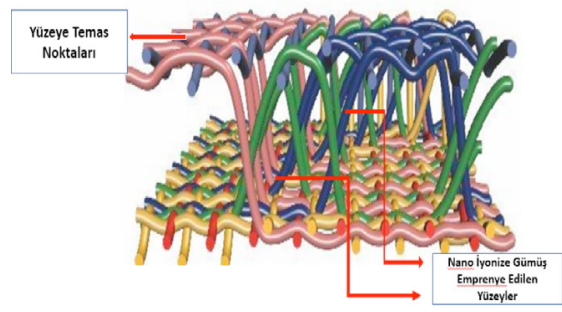

Şekil 1: Üç boyutlu kumaş kullanılarak nano gümüş emprenye edilecek yüzeyler

\section{Deneysel Çalışmalar}

\section{1.Ụ̧̈ Boyutlu Kumaşlar}

Antimikrobiyal örtü için üç boyutlu kumaş örnekleri üzerinde, Makine İleri Teknolojiler Laboratuvarı (MiT LAB)'da bulunan optik mikroskop ile örnek kumaşlar arasında incelemeler yapıldı ve örnek kumaşların mikroyapı (X1000 büyütme ile) görüntüleri incelenmiştir (şekil 2).

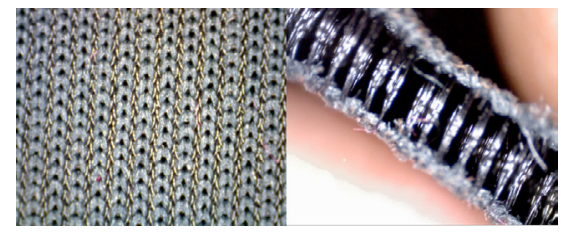

Şekil 2: Üç boyutlu kumaşın optik mikroskop altındaki yüzey ve ara kesit görüntüsü

\subsection{Nano Gümüş Sentezi}

Nano gümüş emprenye solüsyonun hazırlanması ve sentezi için ilk aşamada $0,001 \mathrm{M} \mathrm{AgNO}_{3}$ ve $100 \mathrm{ml}$ deiyonize su hazırlandı. Daha sonra hazırlanan karışım 1sitılmaya başlandı ve kaynamasıyla birlikte $\mathrm{AgNO}_{3}$ çözeltisi içine $5 \mathrm{ml} \% 1$ trisodyum sitrat çözeltisi her 3 sn ara ile birer damla eklendi. Trisodyum sitrat eklenen $\mathrm{AgNO}_{3}$ çözeltisi renk değiştirmeye başlamasıyla birlikte nano gümüş içerikli emprenye solüsyonun hazır hale geldiği görüldü.

\section{3. Üç Boyutlu Kumaşlarda Nano Gümüş Emprenye İşlemi}

Nano gümüş emprenye işlemi için, ilk önce örnek üç boyutlu kumaşlar istenilen boyut ve formda hazırlandı ve temizleme işlemine tabi tutuldu. Temizleme işlemi için kullanılan temizlik solüsyonu $500 \mathrm{~mL}$ su ve 2 ölçek arap sabunu kullanılarak hazırlandı. Kumaşlar $20 \mathrm{dk}$ boyunca temizlik solüsyonuna bırakıldı. Temizlik solüsyonundan çıkarılan kumaşlar, deiyonize su ile durulandıktan sonra kurumaları için kurutma etüvüne konuldu. Kumaşlar 2 saat, 80 oC sıcaklıkta kurutulmaya bırakıldı. Kuruyan kumaşlar hazırlanan nano gümüş çözeltisin içerisine konuldu. Nano gümüş çözeltisi için $6,75 \mathrm{ml}$ nano gümüş̧ çözeltisi ve $500 \mathrm{ml}$ deiyonize su kullanıldı. Nano gümüş çözeltisi içine konulan kumaşlar bir gece boyunca nano gümüş çözeltisi içinde bekletildi. Böylelikle, üç boyutlu kumaşların yapısından dolayı nano gümüş çözeltisini daha iyi emprenye edilmesi sağlandı. Daha sonra, kumaşlar deiyonize su ile tekrar durulandı ve tekrar 80 ${ }^{\circ} \mathrm{C}$ 'ye ayarlanan etüve 2 saat sürede kuruma amaciyla konuldu.

\section{Nano Gümüiş Emprenye Edilen Üç Boyuthu Kumașlarmn Mikroorganizmalara Karşı Etkinliklerinin Incelenmesi}

Nano gümüş emprenye edilen üç boyutlu kumaşlarn mikroorganizmalara karşı etkinliklerinin incelenmesi için mikroorganizmaların yoğun bulunduğu bir ortama ihtiyaç 
vardır. Bunun için maya (Saccharomyces cerevisiae) kullanılmıștır. Bunun için maya (Saccharomyces cerevisiae) kullanılmıştır. Mayalar, doğada her yerde bulunabilen ve tek hücreden oluşan mikroorganizmalardır [10]. Mayalar tomurcuklanarak çoğalmaktadır. Maya içindeki mikroorganizmaların çoğalması için 1 lık suya $\left(20^{\circ}\right.$ $\mathrm{C}-32^{\circ} \mathrm{C}$ ) bir küp şeker ilave edilir. Böylelikle 1 lık su ile maya mikroorganizmalarının çoğalması için bir ortam sağlanırken şeker kullanarak da maya mikroorganizmalarının beslenmesi sağlamış olur. Maya kullanılmasının bir diğer sebebi ise mayanın içeriğinde bulunan genlerin, insan genlerine çok benzer olmasıdır. Maya hücreleri yuvarlak veya oval şeklinde olup, boyutları 2-3 $\mu \mathrm{m}$ ile 20-50 $\mu \mathrm{m}$ arasında değişir. 1 gr yaş maya yaklaşık 10 milyar hücre içerir [10].

\subsection{Antimikrobiyal Etkisi Yüzde Yüz Olan Referans Kumaş}

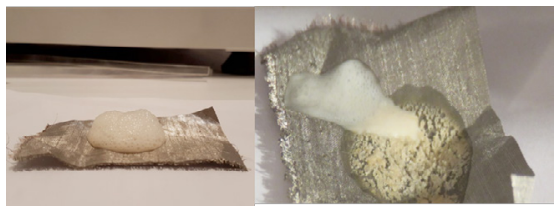

Şekil 3: Referans kumaşın mikroorganizmalara karşı etkinliği

Antimikrobiyal etkisi yüzde yüz olan referans kumaşın (yüzde yüz gümüş fiberler kullanılarak örülmüş saf gümüş içerikli kumaş formunda) mikroorganizmalara karşı nasıl bir etkinlik gösterdiğini incelemek için 1 paket yaş maya (42 g) kullanılmıştır. Maya 1lık su ve şeker konularak karıştırıldıktan sonra etüvde $35^{\circ} \mathrm{C}$ 'de içine birmiktarsukonulmuştur.Bu sayede firıniçinemli ve sıcak olup mikroorganizmaların yaşayıp çoğalması için uygun bir ortam sağlanmıştır. Hazırlanan karışım, mikroorganizmalara karşı antimikrobiyal etkisi yüzde yüz olan referans kumaş üzerine konularak mikroorganizmalara karşı etkinlikleri test edilmiştir. Kumaş üzerine hazırlanan karışım koyulduktan sonra kumaş mikroorganizmaların yaşayabilmesi için uygun ortam sağlanan sıcak ve nemli olan firına konuldu ve 10 dakika beklenildikten sonra kumaş incelendi. Mikroorganizmalara karşı antimikrobiyal etkisi yüzde yüz olan referans kumaş üzerine konulan karışımın köpürmediği görülmektedir. Böylelikle, kumaş üzerinde mikroorganizmaların çoğalmadığı ve kısa sürede yok olmaya başladığı kuruyarak ölü bir katman haline geldiği görülmüştür (Şekil 3).
4.2. Antimikrobiyal Etkisinin Üç Boyutlu Kumaşlarda İncelenmesi

Üç boyutlu kumaşların mikroorganizmalara karşı etkinliklerini incelemek için 40-42 g yaş maya kullanılmıştır. Maya 1 lık su ve şeker konularak karıştırıldıktan sonra etüv $35^{\circ} \mathrm{C}$ 'ye ayarlanıp içine ortamin nemlendirmesi amaciyla bir miktar su konulmuştur. Böylelikle, etüv içi nemli ve sıcak olup mikroorganizmaların yaşayıp çoğalması için uygun bir ortam haline gelmiştir. Nano gümüş emprenye edilmiş kumaşlarla ve sadece temizlenen emprenyesiz kumaşların üstlerine maya konularak mikroorganizmalara karşı antimikrobiyal etkisi gözlemlenmiştir. Hazırlanan karışım nano gümüş emprenye edilmeyen kumaşlar üzerine konuldu.

Nano gümüş emrenye edilen ve nano gümüş emprenye edilmeyen şahit kumaşlar üzerine maya konulduktan $3 \mathrm{dk}$ sonra ilk incelemede, nano gümüş emprenye edilen üç boyutlu kumaşlarda maya köpürmesinin kısa sürede söndüğünü görüldü. Bu da o kumaş üzerinde maya hücrelerinin yaşayamadığı anlamına gelmektedir. Nano gümüş emprenye edilmeyen şahit kumaşlarda ise maya köpürmesi devam etmiş ve maya hücreleri yaşamaya devam ettiği gözlemlenmiştir. Nano gümüş emprenye edilen kumaşlar üzerinde köpürme olmadığı gibi hazırlanan karışım sönüp kumaş üzerinde kalmakta ve kumaş içine nüfuz etmemektedir. Diğer yandan, nano gümüş emprenye edilmeyen şahit kumaşlar üzerinde köpürme devam etmekte ve kumaşa nüfuz etmektedir.

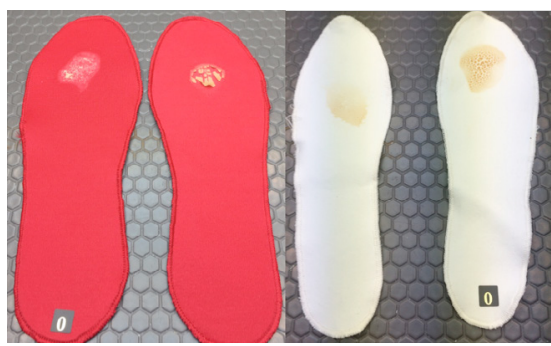

Şekil 4: Nano gümüş emprenye edilmeyen [0] kodlu şahit kumaş ve nano gümüs emprenye edilen örnek kumaşta 24 saat sonraki görünümleri

Kumaşlar 24 saat sonra incelendiğinde hazırlanan karışımın nano gümüş emprenye edilen kumaşlar yüzeyinde maya bakterileri üreyip gelişemeden kumaş üzerinde ölü ve kuru bir tabaka oluşturmuş. Nano gümüş emprenye edilmeyen kumaşlarda ise maya bakterileri gelişip kumaş içine nüfuz ettikten sonra kuruduğu görülmektedir (Şekil 4). Bunu kaplanmamış kumaşlarda daha net görebiliyoruz çünkü kumaş 
yüzeyinde maya bakterileri üreyip çoğaldıkları için daha yoğun bakteri kümeleri oluşmuştur.

\section{Sonuç}

Mikroorganizmaların tekstil materyali üzerinde kontrolsüz çoğalması, tekstil materyali üzerinde renk değişimi, kötü koku, tutum özelliklerinin kötüleşmesi, performans özelliklerinin olumsuz etkilenmesi gibi pek çok istenmeyen sonuca neden olmaktadır. Antimikrobiyal tekstiller ilk kullanılmaya başlandıklarında, kullanımları sadece toplu yaşam alanları ile sınırlı iken günümüzde, kişisel kullanım, giysi, ev tekstili, bebek tekstil ürünleri ve ev hayvanları için tekstil ürünleri şeklinde de kullanımları çeşitlenmiş ve artmıştır.

$\mathrm{Bu}$ çalışmada, nano gümüş iyonlarının yüksek yüzey alanına sahip olmaları ve antimikrobiyal özelliğinin olmasından dolayı ayrıca insan vücuduna toksik etki yaratmamasından dolayı tercih edilip üç boyutlu kumaşlara emprenyesi gerçekleştirilmiştir. Nano gümüş emprenye edilen antimikrobiyal örtülerin mikroorganizmal özelliklerinin iyonize nano gümüş miktarı ile doğru orantılı olduğu için üç boyutlu kumaşlara emprenyesi gerçekleştirilmiştir. $\mathrm{Bu}$ da nano iyonize gümüşlerin antimikrobiyal örtüde daha çok olmasını ve antimikrobiyal örtünün daha fazla antimikrobiyal etkinliğe sahip olmasını sağlamıştır. Nano gümüş emprenye edilen örnek kumaşların maya hücrelerine karşı etkinliğini görebilmek için maya bakterileri kullanılmıştır. Maya kullanılarak test edilen, nano gümüşlü ve nano gümüşsüz kumaşlar $3 \mathrm{dk}$ gibi kısa süre zarfında incelendiğinde kaplamasız kumaş üzerinde bakterilerin çoğaldığı, nano gümüş emprenye edilen kumaşlar üzerinde bakterilerin çoğalmadığı tam tersi yok olduğu gözlemlenmiştir. Ayrıca nano gümüş emprenye edilen üç boyutlu kumaşların yüzeylerinde bulunan maya karışımı sönmeye devam etmekte olup ve kumaşa bakterilerin nüfus etmediği görülmüştür. Ancak, nano gümüş emprenye edilmeyen üç boyutlu kumaşların yüzeylerinde köpürmenin devam ettiği ve maya hücrelerinin kumaşa nüfus ettiğini gözlenmiştir. Kumaşlar 24 saat sonra incelendiğinde hazırlanan karışımın nano gümüş emprenye edilen kumaşlar yüzeyinde maya hücreleri üreyip gelişemeden kumaş üzerinde ölü ve kuru bir tabaka oluşturmuştur. Nano gümüş emprenye edilmeyen kumaşlarda ise maya hücreleri gelişip kumaş içine nüfuz etmiş ve kurumuş ve kumaş yüzeyinde maya hücreleri üreyip çoğaldıkları için daha yoğun maya hücre kümeleri oluşmuştur. 


\section{KAYNAKLAR}

1. De Matteis, V., et al., "Negligible particle-specific toxicity mechanism of silver nanoparticles: the role of Ag+ ion release in the cytosol" Nanomedicine, 2015. 11(3): p. 731-9.

2. Rai, M. K., Yadav, A. P., Gade, A. K., "Silver nanoparticles as a new generation of antimicrobials" .Biotech Adv. 2009, 27 (1): 76-82.

3. Diana Santos Morais, Rui Miranda Guedes and Maria Ascensão Lopes "Review-Antimicrobial Approaches for Textiles: From Research to Market" Materials 2016, 9, 498;

4. Gokarneshan N and Velumani K "Application of Nano Silver Particles on Textile Materials for Improvement of Antibacterial Finishes" Glob J Nanomed 2(2): GJN.MS.ID.555586 (2017)

5. Soyalp, V., (2015) ”Nano Gümüş Teknolojisi” "https://cepkolik.com/”ttps://cepkolik.com

6. Barbara Simonc `ic` and Danijela Klemenc`ic "Preparation and performance of silver as an antimicrobial agent for textiles: A review” Textile Research Journal 0(00) 1-14, 2015

7. Landage S. M. and Wasif A. I. "Nanosilver - An Effective Antimıcrobial Agent For Finishing of Textiles" International Journal of Engineering Sciences \& Emerging Technologies, Dec. 2012. Volume 4, Issue 1, pp: 66-78

8. Yıldırım, M., 2008, “Üç Boyutlu Boşluklu Yuvarlak Örme Kumaşların Antistatik ve Isıl Özelliklerinin Belirlenmesi”, Erciyes Üniversitesi Fen Bilimleri Enstitüsü, Yüksek Lisans Tezi, Kayseri, 133s.

9. http://www.scotweave.com (14Mayıs 2018)

10. http://yuvamaya.com.tr (14 Mayıs 2018) 